\title{
The study of electricity-saving behavior of personnel at Phranakhon Rajabhat University.
}

\author{
Somprasong Choklap ${ }^{1}$, Rachadaporn Boonruang, ${ }^{2}$ and Tipat Sottiwan ${ }^{3}$ \\ ${ }^{1}$ Students of the Master of Business Administration Program, Faculty of Management \\ Science, Phranakhon Rajabhat University, Bangkok, Thailand \\ ${ }^{2}$ Head of the Master of Business Administration Program, Faculty of Management Science, \\ Phranakhon Rajabhat University,Bangkok, Thailand \\ ${ }^{3}$ Professor of Applied Statistics Rajamangala University of Technology \\ Thanyaburi,Phatumthani Province, Thailand
}

\begin{abstract}
This research aimed to study the electricity-saving behavior of personnel at Phranakorn Rajabhat University. The samples consisted of 276 Phranakorn Rajabhat University's personnel who worked during the academic year 2019. Multi-staged sampling techniques were used for samples selection. Data were collected by a questionnaire. Statistics employed were percentage, arithmetic mean, standard deviation, pearson product-moment correlation The research found that; information reception, attitude, and electricity-saving behavior were at high levels, whereas knowledge was at median. Relationship studies revealed that information reception, attitude, and electricity saving behavior of personnel at Phranakorn Rajabhat university were positively related in the same direction at significant level of .01.
\end{abstract}

Key words: Electricity-saving behavior, information reception, knowledge, attitude.

\section{STATEMENT OF THE PROBLEM}

Energy crisis arose in the year 1973. The government set a policy to conserve energy by means of fuel and electricity saving which led to the conservation of energy saving regulation in the year 1992. The increase in electricity production to satisfy the never ending demand creates impact on the environment by releasing carbon dioxide to the atmosphere and also rise the cost of electricity in Thailand) Department of Alternative Energy Development and Efficiency, (15-1 :2007. Because of the limitation of natural resources, production of electricity always fluctuates thus importation of resources from abroad are necessary. However transportation cost drives up the cost of electricity production to meet the rising demand )Office of Environmental Policy and Planning, 2006: 15-19.( The reduction in demand will reduce the cost and affect to lower the cost of all other goods. Because of this reason, there is a need to increase the people's attitude to conserve energy for maximum benefits. This requires interest and cooperation from various parties to achieve the goal )Energy Forecast and Information Center Energy Policy and Planning
Office, 2012: 1-21(.Phranakorn Rajabhat University is established at 9 Chaeng Wattana road, Anusawari Subdistrict, Bang Khen District, Bangkok. The area covers 198 rai and 66 Buildings. The university uses a lot of energy from lighting, air-conditioning, elevators, generators, water treatment, and all educational tools and equipment. The records showed that the university use electricity as follows; year 2557: 35,923,486.10 baht, year 2558: 39,976,791.30 baht, year 2559: 42,169,104.20 baht, year 2560: 40,722,571.76 baht, year 2561: 41,036,907.59 baht and year 2562: 43,052,434.87 baht. The figures show rising consumption every year.The university continuously set up campaigns for electricity reduction, however the efforts seen to be not really successful. The behaviours of the personnel have not change; for example, set airconditioning temperature too low or leave light on when not in use. Therefore in order to reduce electricity cost and encourage environmental sustainability the university has announced the rules of energy saving for all personnel to follow )Division of Building and Environment Phranakhon Rajabhat University .(2019-2014The reduction of electricity demand will decrease the production cost 
of other goods as well. To solve many problems, most government departments are interested and participate in energy conservation to reduce energy consumption )Energy Forecast and Information Center Energy Policy and Planning Office, 2012: 121(. From these reasons the researcher sees the importance in studying the electricity-saving behaviour of Phranakorn Rajabhat University's personnel. The result will enable the action of electricity saving successfully and achieve the objective of the university.

\section{LITERATURE REVIEWS}

There was no interaction effect between the positive attitude to electrical energy saving and the electrical energy saving model on electric energy saving behavior of civil servants in offices, Ministry of Education. There was interaction effect between awareness of problem of electrical energy shortage and perception in the news/information of electrical energy on the electrical energy saving behavior of civil servants in offices. Psychological and social factors predicted 53 percent of variance in electrical energy saving behavior of civil servants in offices, Ministry of Education in both over all group and bio - social group. In over all group, There were also 4 significant predictors; 1) positive attitude toward electric energy saving, 2) self - perception on electrical energy saving, 3) electrical energy saving model and 4) perception in the news/information of electrical energy saving, The important predictors were electrical energy saving model and the positive attitude toward electrical energy saving.[1]The people living in Muang District, Buriram Province, There was no relationship between knowledge of residential energy saving and energy saving behaviors. However, knowledge of energy saving showed the relationship to saving behaviors in the aspects of choosing to buy the electrical appliance and maintaining electrical appliances. Government and private sectors should promote, encourage and provide accurate and clear information for choosing and buying suitable electrical appliances through various media, such as television and leaflets from Electricity Generating Authority of Thailand to increase the awareness and understanding of people.People should be encouraged and educated on correct and proper methods of using household electrical appliances from manufacturers, distributors, sales representatives and government public relations units for more knowledge and correct use.People should be informed and urged on appropriate procedures of electrical appliances maintenance to have good and correct maintenance techniques through free handouts, calendars or stickers which are for encouraging the people to use and repair the electrical appliance in the correct way. [2] The study factors were 7 independents factors, which were 3 psychological trait factors (well-being, moral reasoning and future orientation and selfcontrol), 1 psychological state factor (positive attitude towards be saving behavior), and 3 situation factors (appropriate model from family, knowledge on the electrical energy saving and the information about electricity saving). The dependent factor was the electrical energy saving behavior.[3] The relationship between knowledge and energy conserving behavior among government officials, privates, and employees working for Fleet Training Command were a low relationship between the subject's level of knowledge and behavior in conserving energy at a significant level at $0.01(\mathrm{r}=$ 0.201).[4] the different numbers of hours spent in the university had effect on saving energy in the Nationwide Energy Saving Campaign", and the campaign to save energy correlated to the average level in the same direction with the behavior recognition to save energy in the Nationwide Energy Saving Campaign.[5] Three factors, which were the knowledge regarding the energy-saving, acknowledgement of the news concerning the energy-saving, the value giving toward the energy, influenced the energy-saving behavior in the workplace of the employees of Leo Medical Co., Ltd. with the statistical significance at the level of 0.05 The finding of the study will be beneficial for the Executives in awareness cultivation among the employees to. [6] The respondents get the news regarding energy saving every day and interested in the information about energy saving. The average amount of time of electrical energy use was 7.99 hours per day. The average amount of time of office equipment use was 6.44 hours per day. The average amount of time of electrical equipment use for entertainment was 2.97 hours per day. The average amount of time of electrical equipment use for comfort was 6.19 hours per day. [7]

Research Objective

To study the electricity-saving behavior of the personnel of Phranakorn Rajabhat University.

Scope of the research

1. Scope of the content:This research aimed to study the electricity-saving behavior of personnel of Phranakorn Rajabhat University. The researchers studied concepts and theories of human behavior, information reception, knowledge, and attitude for this research.

2. Independent variables were information reception, knowledge, and attitude. Dependent variable was electricity-saving behavior.

\section{METHODOLOGY}

This research was a quantity research and the data were collected as follows;

1. Population and sample:

1.1 Population was the Phranakorn Rajabhat University's personnel both academic and academic-supporters who worked during the academic year 2019, totaling 882 people. 
1.2 The samples were calculated by Taro Yamane's formula at $95 \%$ level. The samples were 276 respondents. Stratified random sampling method and accidental sampling were used for sample selection.

2. A questionnaire was used for data collection. They consisted of 5 sections of electricity-saving behavior. Section 1 was demographic factors. Section 2 was information reception. Section 3 was knowledge on electricity saving. Section 4 was attitude on electricity saving. Section 5 was on electricity-saving behavior.

3. Statistics employed for data analysis;
3.1 Study of information reception, knowledge, attitude, and electricity saving behavior by descriptive statistics of frequency, arithmetic mean, and standard deviation.

3.2 Study of relationship between variables by inferential statistics of Pearson product-moment correlation coefficient.

3.3 Study of forecast analysis by Stepwise multiple regression analysis.

\section{Research Findings}

1. Electricity-saving behavior of Phranakhon Rajabhat University's personnel revealed;

Table 1 Display arithmatic mean and standard deviation of the information reception of electricity-saving by items and total.

\begin{tabular}{|c|c|c|c|}
\hline \multirow{2}{*}{$\begin{array}{l}\text { Factors affecting electricity-saving behavior } \\
\text { Factors of information reception }\end{array}$} & \multicolumn{2}{|l|}{$n=276$} & \multirow[t]{2}{*}{ Level } \\
\hline & & SD & \\
\hline $\begin{array}{l}1 \text {.You know about the campaign for electricity- } \\
\text { saving of Phranakhon Rajabhat University. }\end{array}$ & 4.00 & 0.703 & High \\
\hline $\begin{array}{l}\text { 2. When mention about electricity-saving, you will } \\
\text { think of turning off the lights first. }\end{array}$ & 4.42 & 0.616 & Highest \\
\hline $\begin{array}{l}\text { 3. You always read about electricity-saving from } \\
\text { various journals. }\end{array}$ & 3.43 & 0.867 & High \\
\hline $\begin{array}{l}\text { 4. You always read electricity-saving procedure } \\
\text { posted in class rooms. }\end{array}$ & 3.44 & 0.879 & High \\
\hline $\begin{array}{l}\text { 5. You always read electricity-saving procedure } \\
\text { posted in elevators. }\end{array}$ & 3.61 & 0.818 & High \\
\hline $\begin{array}{l}\text { 6. You always read electricity-saving procedure } \\
\text { posted in faculty/center/office. }\end{array}$ & 3.61 & 0.824 & High \\
\hline $\begin{array}{l}\text { 7. You always see message on turning off lights at } \\
\text { electricity outlets and switches. }\end{array}$ & 3.71 & 0.890 & High \\
\hline $\begin{array}{l}\text { 8. You watch advertisements on electricity-saving on } \\
\text { TV. }\end{array}$ & 3.46 & 0.878 & High \\
\hline 9. You read internet on electricity-saving. & 3.29 & 0.830 & Medium \\
\hline 10. Message on electricity-saving is interesting. & 3.85 & 0.975 & High \\
\hline Average & 3.68 & 0.543 & High \\
\hline
\end{tabular}

Table 1 shows that factors affecting the electricitysaving behavior of Phranakhon Rajabhat University's personnel, factors of information reception by items and total are in high level. Rankings order from high to least are:

- When mention about electricity-saving, you will think of turning off the lights first.
- You know about the campaign for electricitysaving of Phranakhon Rajabhat University.

- Message on electricity-saving is interesting.

Table 2 Display frequency and percentage of knowledge on electricity-saving by items and total.

\begin{tabular}{lllll}
$\mathrm{n}=276$ & \multicolumn{3}{l}{ Incorrect } \\
\hline Knowledge on electricity-saving & Correct & & Percentage \\
\cline { 2 - 5 } & Frequency & Percentage & Frequency & Perces \\
\hline $\begin{array}{l}\text { 1. Electric appliances with high wattage consume less } \\
\text { electricity. }\end{array}$ & 230 & 83.3 & 46 & 16.7 \\
$\begin{array}{l}\text { 2. Cleaning light bulbs make them fully bright and } \\
\text { save electricity. }\end{array}$ & 194 & 70.3 & 82 & 29.7 \\
\hline
\end{tabular}




\begin{tabular}{|c|c|c|c|c|}
\hline $\begin{array}{l}\text { 3. Television, computer, when not use should remove } \\
\text { plug to save electricity. }\end{array}$ & 256 & 92.8 & 20 & 7.2 \\
\hline $\begin{array}{l}\text { 4. Careful choosing of a computer screen can save } \\
\text { electricity. } 14 \text { " screen use less electricity than } 17 \text { " } \\
\text { screen. }\end{array}$ & 175 & 63.5 & 101 & 36.5 \\
\hline 5. Plug in kettle always, save electricity. & 225 & 81.5 & 51 & 18.5 \\
\hline 6. Ventilation fan always on, save electricity. & 108 & 39.2 & 168 & 60.8 \\
\hline $\begin{array}{l}\text { 7. Cleaning air-conditioning filter do nothing to save } \\
\text { electricity. }\end{array}$ & 142 & 51.5 & 134 & 48.5 \\
\hline $\begin{array}{l}\text { 8. To save electricity air-conditioning should be set at } \\
24 \text {. }\end{array}$ & 144 & 52.2 & 132 & 47.8 \\
\hline $\begin{array}{l}\text { 9. Thailand can produce enough electricity for its } \\
\text { consumption. }\end{array}$ & 216 & 78.2 & 60 & 21.8 \\
\hline $\begin{array}{l}\text { 10. Light color wall and ceiling will reflect and help } \\
\text { use less bulbs. }\end{array}$ & 184 & 66.7 & 92 & 33.3 \\
\hline
\end{tabular}

Table 2 found that factors affecting the electricitysaving behavior of Phranakhon Rajabhat University's personnel, factors of knowledge by items and total are in medium level. Rankings order from high to least are:
- Television, computer when not in use should remove plug to save electricity.

- Electric appliances with high wattage consume less electricity.

- Plug in kettle always, save electricity.

Table 3 Display arithmetic mean and standard deviation of the attitude to save electricity by items and total

\begin{tabular}{|c|c|c|c|}
\hline \multirow{2}{*}{$\begin{array}{l}\text { Factors affecting electricity-saving behavior } \\
\text { Factors of attitude }\end{array}$} & \multicolumn{2}{|c|}{$\mathrm{n}=\mathbf{2 7 6}$} & \multirow[t]{2}{*}{ Level } \\
\hline & $\bar{x}$ & SD & \\
\hline 1. Saving electricity is everyone duty. & 4.71 & 0.580 & Highest \\
\hline 2. It is time to help save electricity urgently. & 4.74 & 0.502 & Highest \\
\hline $\begin{array}{l}\text { 3. Family and school are an important part to establish } \\
\text { electricity-saving behavior in minors. }\end{array}$ & 4.63 & 0.616 & Highest \\
\hline 4. You feel that you must save-electricity. & 4.67 & 0.589 & Highest \\
\hline 5. You play your part in saving electricity at work. & 4.56 & 0.705 & Highest \\
\hline 6. Not help saving electricity do no harm. & 3.25 & 1.681 & Medium \\
\hline $\begin{array}{l}\text { 7. You think you do not need to save-electricity at } \\
\text { work. }\end{array}$ & 2.18 & 1.489 & Low \\
\hline $\begin{array}{l}\text { 8. The university consume lots of electricity, everyone } \\
\text { must feel responsible to save. }\end{array}$ & 4.57 & 0.788 & Highest \\
\hline $\begin{array}{l}\text { 9. Electricity spending in the university has impact on } \\
\text { salary of personnel. }\end{array}$ & 2.87 & 1.606 & Medium \\
\hline $\begin{array}{l}\text { 10. Turning off computer screen during lunch break } \\
\text { can help saving electricity at work. }\end{array}$ & 4.12 & 0.813 & High \\
\hline 11. You are entitled to use appliances at work fully. & 2.88 & 1.258 & Medium \\
\hline $\begin{array}{l}\text { 12. LED bulbs save more electricity than traditional } \\
\text { bulbs, even it is more expensive, we should change. }\end{array}$ & 3.92 & 0.779 & High \\
\hline $\begin{array}{l}\text { 13. Constant repair and maintenance of appliances } \\
\text { help save electricity. }\end{array}$ & 4.07 & 0.788 & High \\
\hline $\begin{array}{l}\text { 14. Walking up and down instead of using elevator } \\
\text { helps save electricity. }\end{array}$ & 4.60 & 0.753 & Highest \\
\hline $\begin{array}{l}\text { 15. You press elevator repeatedly because it will come } \\
\text { faster. }\end{array}$ & 1.77 & 1.048 & Least \\
\hline Average & 4.09 & 0.439 & High \\
\hline
\end{tabular}


Table 3 Show that factors affecting the electricitysaving behavior of Phranakhon Rajabhat Universitys personnel, factors of attitude by items and total are in high level. Rankings order from high to least are:
-It is time to help save electricity urgently.

-Saving electricity is everyone duty.

-You feel that you must save-electricity.

Table 4 Display arithmetic mean and standard deviation of electricity-saving behavior of Phranakhon Rajabhat University's personal by items and total.

\begin{tabular}{|c|c|c|c|}
\hline $\begin{array}{l}\text { Electricity-saving behavior of personnel at } \\
\text { Phranakhon Rajabhat University }\end{array}$ & $\mathrm{n}=\mathbf{2 7 6}$ & SD & Level \\
\hline .1 You turn off lights and appliances when done. & 4.50 & 0.641 & Highest \\
\hline 2. You switch off appliances and unplug. & 4.17 & 0.954 & High \\
\hline $\begin{array}{l}\text { 3. When you see an empty room with light on, you } \\
\text { will turn it off. }\end{array}$ & 4.13 & 0.916 & High \\
\hline 4. You turn on lights only in working area. & 4.20 & 0.848 & High \\
\hline $\begin{array}{l}\text { 5. If you are last to leave, you will check and turn off } \\
\text { all lights in offices and class rooms. }\end{array}$ & 4.28 & 0.781 & Highest \\
\hline 6. You turn off light in toilet when done. & 4.44 & 0.859 & Highest \\
\hline 7. You turn off light during lunch break 12.00-13.00. & 3.70 & 1.025 & High \\
\hline $\begin{array}{l}\text { 8. If you see air-conditioning not set at } 25 \text {, you will } \\
\text { reset to } 25 \text {. }\end{array}$ & 3.85 & 0.979 & High \\
\hline $\begin{array}{l}\text { 9. If you come to work alone, you turn on air- } \\
\text { conditioning immediately. }\end{array}$ & 2.84 & 0.972 & Medium \\
\hline $\begin{array}{l}\text { 10. Even it is hot, you don't turn on air-conditioning } \\
\text { until } 8.15 \text {. }\end{array}$ & 3.35 & 0.993 & Medium \\
\hline $\begin{array}{l}\text { 11. You turn off air-conditioning at } 11.45 \text { and turn it } \\
\text { on again at } 13.00 \text {. }\end{array}$ & 3.31 & 0.956 & Medium \\
\hline $\begin{array}{l}\text { 12. You will turn off air-conditioning when you finish } \\
\text { during office hour. }\end{array}$ & 3.50 & 1.045 & High \\
\hline 13. You walk when need to go one floor. & 4.45 & 0.872 & Highest \\
\hline 14. Using elevator, you wait for other. & 3.51 & 0.958 & High \\
\hline 15. You open curtain to get natural light. & 3.46 & 1.015 & High \\
\hline Average & 3.86 & 0.501 & High \\
\hline
\end{tabular}

Table 4 show that the electricity-saving behavior of Phranakhon Rajabhat University's personnel by items and total are in high level. Rankings order from high to least are:

- You turn off lights and appliances when done.

- You walk when need to go one floor.

- You turn off light in toilet when done.
.2 Factors affecting the electricity-saving behavior of Phranakhon Rajabhat University's personnel from table 5 revealed that; information reception factors $(\mathrm{r}=0.393)$, and attitude factors $(r=0.377)$ have relationships with electricity-saving behavior of Phranakhon Rajabhat University's personnel in the same direction at significant level of .01 . 
Table 5 The correlation coefficient between factors affecting the electricity-saving behavior of personnel at Phranakhon Rajabhat University.

Factors affecting the electricity-saving behavior of personnel at Phranakhon Rajabhat University

Electricity-saving behavior

\begin{tabular}{llllll}
\hline $\begin{array}{l}\text { Factors } \\
\text { Information } \\
\text { reception }\end{array}$ & $\begin{array}{l}\text { Factors } \\
\text { Knowledge }\end{array}$ & $\begin{array}{l}\text { Factors } \\
\text { Attitude }\end{array}$ \\
\hline $\mathbf{r}$ & $\mathbf{P}$ & $\mathbf{r}$ & $\mathbf{P}$ & $\mathbf{r}$ & $\mathbf{P}$ \\
$* * 0.393$ & 0.000 & 0.053 & 0.286 & $* * 0.377$ & 0.000 \\
\hline
\end{tabular}

$* * \mathrm{p}<.01$

3 .The analysis result for forecast equation for electricity-saving behavior of personnel at Phranakhon Rajabhat University found that information reception variable (X1) and attitude variable (X3) can explain the variant of electricitysaving behavior of personnel at Phranakhon Rajabhat University at) $48.8 \mathrm{R}^{2}=0.488$ (

\section{Forecasting equations in raw scores}

\section{CONCLUSIONS}

.1 The research found that, information reception, knowledge and attitude affected the electricitysaving behavior of the Phranakhon Rajabhat University's Personnel in the high level. It is because the university has launched electricitysaving campaign to various departments through many activities for a long time. It is in line with (Suparinya Limwananan ((2016 conducted a research of Factors Affecting the Electricity Saving Behavior in the Workplace of Employees of the Leopard Brand Pharmacy Department. Her research found that the samples had high attitude on electricity-saving. Thaphat Phirom ( (63-1 :2015 conducted a research factors influencing the participation in electricity conservation of Mahasarakham University students.His research found knowledge of electricity saving at medium .level

.2 The electricity-saving behavior of the university's personnel is at high level. It may due to the fact that they all see the importance and participate in programs such as; switch off electricity when done, or walk instead of using elevator for one-floor usage. It is in line with Suparinya Limwananan ((2016 which found the electricity-saving behavior of the personnel of the Leopard Brand Pharmacy Department .in the high level Jamnida Kananan ( (2012conducted a research psychosocial factors related to electrical saving behavior in the workplace of civil servants, Ministry of Education .Her research found that the electricity-saving behavior of

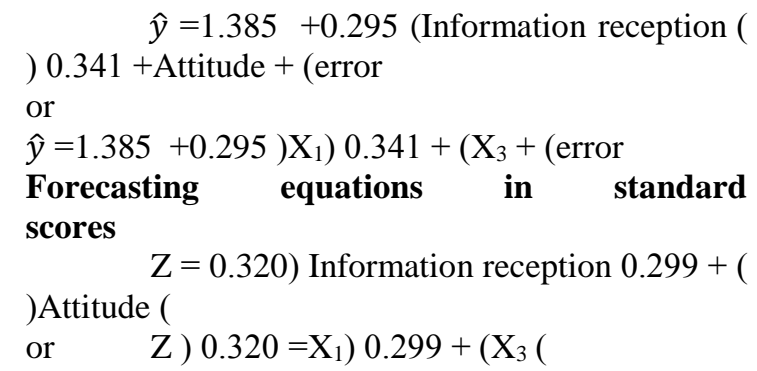

the personnel of Civil servant, Ministry of Educationalso in the high level.

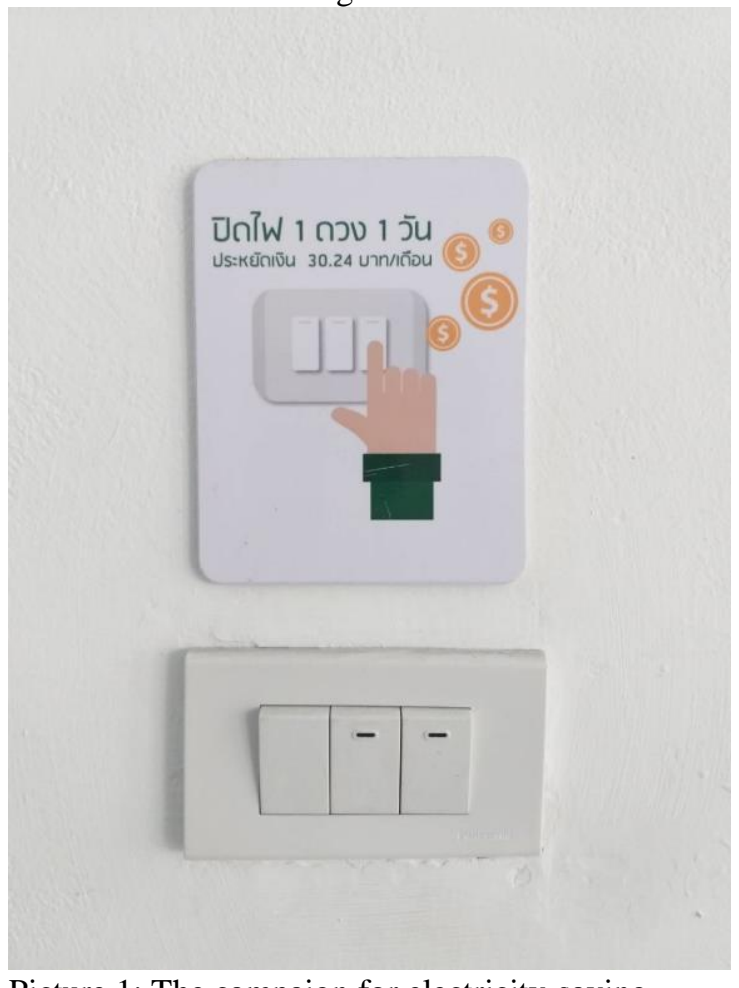

Picture 1: The campaign for electricity-saving

3. In order to establish the electricity-saving behavior of the university's personnel by the forecast equation, the affecting factors consist of information reception, knowledge and attitude. From stepwise multiple regression analysis, it is found that if the management or related persons want the personnel to conserve electricity they must 1) Information reception (X1): create publication 
media such as sticker, poster, banner, electronic circulation letters and VDO clips. 2) Attitude (X3): create events in work place in order to enhance everyone to fully understand and thus change to positive attitude. Tula Mahaphasuthathan

(2002: 184 (found that attitude is a driving force to like or dislike something.

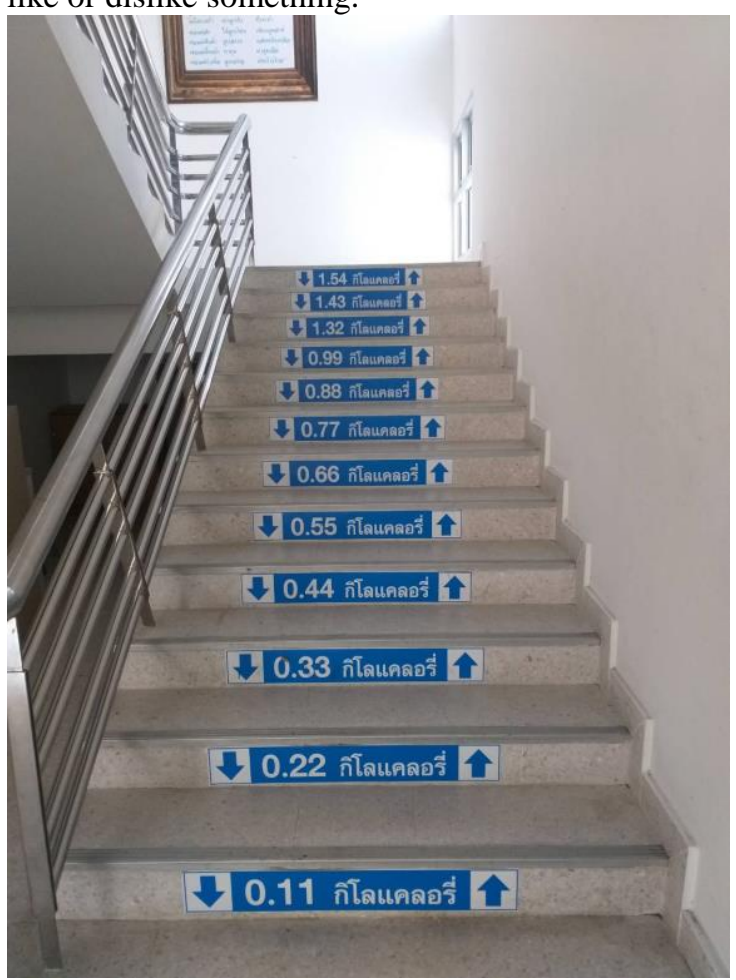

Picture 2: Electricity-saving procedure

It is also in line with Sirirat Uthintaket ( (2011 who conducted a research electricity saving behavior of mathayom suksa six students in Nakhon Ratchasima municipality. Her research found that attitude, information reception about electricity saving from personal sources and journalists had positive impact on saving behavior at the significant level of 0.05 . Attitude explained the fluctuations in saving behavior best, followed by information from personal sources. From the research information from journalists, such as; TV, radio, print all have positive impact. Suparinya Limwananan ((2016 conducted a research of Factors Affecting the Electricity Saving Behavior in the Workplace of Employees of the Leopard Brand Pharmacy Department. Her study found that information reception affected the attitude to save electricity at significant level of 0.05. Jamnida Kananan ( (2012 studied psychosocial factors related to energysaving behavior in the workplace of civil servants, Ministry of Education also found that attitudinal factors and social factors can forecast the willingness to save electricity at the significant level of 0.05

\section{Research suggestion}

This study aimed to give suggestions to create benefits to the management of executive and related personnel.

.1Should promote information reception by means of producing media to encourage electricity saving; such as, posters, stickers, X-banner and circulation of electronic letters to various departments of the university. Also VDO clips should be produced to drive up the interest.

2. Should promote attitude such as, create events, associated with electricity saving and encourage everyone to participate in the events. Correct information will lead to positive attitude about the issue

\section{REFERENCES}

[1] Churairat Thilai (2009) Electricity Saving Behavior in the Workplace of Electricity Generating Authority of Thailand Employees Ratchaburi Power Plant. Master of Arts Degree Thesis, Silpakorn University.

[2] Rungnapha Mhaphom (2008 .(Behavior of Provincial Electricity Authority Employees. To save energy in the workplace. Master thesis, Mahidol University.

[3] Noppadon Lilangrungroj (2014) Factors Related to Electricity Saving Behavior of People in Bangkok Yai District Bangkok. Engineering Journal Siam University, 15 (1), 51-64

[4] Asani Amnuay (2012). Study of conditions and factors affecting household electricity usage behavior and colleges of vocational students in Surin province. Master Thesis of Industrial Education, King Mongkut's University of Technology Thonburi.

[5] Jamnida Kananan (2012). Psychosocial Factors Related to Energy Saving Behavior in The Workplace of Civil Servants. Master of Science Thesis, Ministry of Education, Srinakharinwirot University.

[6] Kitiya Sanguansa (2005) studied the subject of Electricity Saving Behavior of People in Bang Kapi District. This research is part of the business research processing course with computers, Computer Business Department, Faculty of Management Sciences, Chandrakasem Rajabhat University.

[7] Krai Khamwongsa (2015) studied the subject of Factors Influencing Electricity Saving Behavior of People in Phayao Municipality. Independent study, Master of Science Natural Resources and Environmental Management Program, Naresuan University.

[8]Yihua Yu, J. (2016). Identifying electeicitysaving potential in rural China: Empirical evidence from a hold survey. Enegy Policy, 94(July), 1-9. 
Rachadaporn et. al/ International Journal of Business and Management, 4(1) 2020, Pages: 19-26

Department of Energy Economics, School of Economics, Renmin University of China, Beijing 100872, China. 